\title{
TATA KELOLA SISTEM INFORMASI DI PERGURUAN TINGGI SWASTA (MenakarEfektivitasWork From Home)
}

\author{
${ }^{1}$ Danial Kusumah \\ ${ }^{2}$ Sinta Maria Dewi \\ SekolahTinggi Agama Islam Tasikmalaya \\ Program StudiEkonomiSyariah \\ danialkusumah@staitasik.ac.id ${ }^{1}$, sintamaria@ubpkarawang.ac.id ${ }^{2}$
}

\begin{abstract}
Abstrak
Penelitian ini bertujuan untuk mengukur potensi efektivitas kegiatan bekerja dari rumah melalui implementasi sistem informasi pada perguruan tinggi swasta. Jenis penelitian yang digunakan adalah metode analisis deskriptif kualitatif dengan pendekatan studi pustaka. Hasil penelitian menunjukkan apabila perguruan tinggi swasta menerapkan tata kelola sistem informasi secara sistematis dan terstruktur serta didukung oleh mekanisme pengendalian internal yang baik, maka aktivitas bekerja dari rumah dapat berjalan secara efektif. Bekerja dari rumah (work from home) menjadi pola kerja baru pada masa pandemi global covid-19. Untuk menjamin efektivitasnya, diperlukan suatu pengelolaan teknologi informasi yang terencana dan terarah.
\end{abstract}

Kata Kunci: Sistem Informasi, Efektivitas, Work From Home

\begin{abstract}
This study aims to measure the potential effectiveness of work from home activities through the implementation of information systems at private university. This type of research is a qualitative descriptive analysis method with library research approach. The results showed that if private universities implement information systems governance in a systematic and structured manner and supported by good internal control mechanisms, then the activities of working from home can run effectively. Working from home (work from home) became a new work pattern during the global covid-19 pandemic. To guarantee its effectiveness, a planned and directed management of information technology is needed.
\end{abstract}

Keywords: Information Systems, Effectiveness, Work From Home

\section{PENDAHULUAN}

Wabah virus yang disebabkan severe acute respiratory syndrome corona virus 2 (SARS-CoV-2) atau yang lebih dikenal dengan Covid-19 telah mengakibatkan lumpuhnya berbagai aktivitas manusia, baik individu, perusahaan, hingga pemerintahan. Sebaran virus yang bersifat pandemi menyebabkan 185 negara di seluruh belahan dunia terdampak oleh keganasan virus tersebut (WHO, 2020). Tidak terkecuali Indonesia, menurut data Gugus Tugas Nasional Percepatan Penanganan Covid-19, pada bulan April telah terkonfirmasi sebanyak 9.771 kasus positif corona. Berdasarkan informasi yang disampaikan oleh pemerintah beberapa pekan ke belakang, tren kasus Covid-19 menunjukkan eskalasi yang tinggi dengan pola eksponensial. Hal ini memaksa pemerintah untuk memprioritaskan 
penggunaan Anggaran Pendapatan dan Belanja Negara (APBN) 2020 untuk sektor kesehatan. Kebijakan ini diarahkan dalam bentuk produksi alat kesehatan dan pemenuhan kebutuhan rumah sakit. Prioritas fiskal lainnya ditujukan untuk jaring pengamanan sosial, yaitu menambah bantuan sosial guna mempertahankan daya beli masyarakat. Efek domino atas kebijakan ini berimplikasi pada menurunnya aktivitas negara di seluruh lini.

Pendidikan merupakan salah satu sektor yang terkontribusi negatif oleh wabah corona. Pendidikan usia dini, sekolah dasar dan menengah, serta perguruan tinggi dibuat kalang kabut atas ragam aturan yang diberlakukan pemerintah guna memutus rantai penyebaran Covid-19. Lembaga pendidikan diharuskan kreatif dalam mengadaptasi kondisi faktual, sejak dari proses manajerial, kegiatan belajar mengajar, hingga teknis administratif. Perguruan tinggi adalah salah satu entitas pendidikan yang memikul tanggung jawab terberat, yaitu tetap menjamin hak dasar warga negara dalam mengenyam pendidikandi tengah krisis multidimensional ini. Beban tersebut terdapat pada kewajiban utamanya dalam memenuhi Tri Dharma Perguruan Tinggi, yaitu pendidikan, penelitian, dan pengabdian.

Dalam hal penyelenggaraan Tri Dharma Perguruan Tinggi, pemerintah menetapkan Standar Nasional Pendidikan Tinggi (SNPT). Instrumen ini dapat digunakan oleh perguruan tinggi sebagai satuan standar pengelolaan pendidikan, penelitian, dan pengabdian kepada masyarakat. Permenritekdikti No. 44 Tahun 2015 menjelaskan bahwa SNPT terdiri dari: (1) Standar nasional pendidikan memuat standar kompetensi lulusan, standar isi pembelajaran, standar proses pembelajaran, standar penilaian pembelajaran, standar dosen dan tenaga kependidikan, standar sarana dan prasarana pembelajaran, standar pengelolaan pembelajaran, dan standar pembiayaan pembelajaran. Standar pendidikan merupakan alat ukur untuk menetapkan kriteria minimal, identifikasi berbagai aspek yang relevan, dan analisis rancang bangun pelaksanaan sistem pendidikan. (2) Standar nasional penelitian memuat, standar hasil penelitian, standar isi penelitian, standar proses penelitian, standar penilaian penelitian, standar peneliti, standar sarana dan prasarana penelitian, standar pengelolaan penelitian, standar pendanaan dan pembiayaan pembelajaran. Standar ini merupakan pedoman pokok dalam implementasi kegiatan penelitian. Perguruan tinggi adalah produsen ilmu pengetahuan, oleh karena itu lembaga dan seluruh sivitas akademik harus menjamin kontinuitas produksi ilmu. Dosen dan mahasiswa sebagai insan akademik memiliki kewajiban untuk menangkap berbagai fenomena kehidupan di sekitarnya, melakukan telaah, dikembangkan dalam ranah diskusi, dan merumuskan model solutif. (3) Standar nasional pengabdian kepada masyarakat 
memuatstandar hasil pengabdian kepada masyarakat, standar isi pengabdian kepada masyarakat, standar proses pengabdian kepada masyarakat, standar penilaian pengabdian kepada masyarakat, standar pelaksana pengabdian kepada masyarakat, standar sarana dan prasarana pengabdian kepada masyarakat standar pengelolaan pengabdian kepada masyarakat, serta standar pendanaan dan pembiayaan pengabdian kepada masyarakat. Melalui standar pengabdian, tidak hanya reproduksi ilmu pengetahuan, keberadaan perguruan tinggi dengan berbagai aktivitas pendidikan dan penelitian hendaknya ditujukan untuk memberikan kontribusi nyata kepada masyarakat, bangsa, dan negara.

\section{Sistem Penjaminan Mutu Pendidikan Tinggi}

Guna mengendalikan dan meningkatkan penyelenggaraan pendidikan tinggi, diperlukan sebuah kegiatan yang terencana, sistemik, dan berkelanjutan. Bangunan ini dirancang sedemikian rupa untuk menjamin pemenuhan mutu yang disusun dalam sistem penjaminan mutu pendidikan tinggi (SPM Dikti).Perguruan tinggi didorong untuk berkompetisi dalam rangka bertahan hidup dan menghidupi (memberi manfaat). Untuk itu, tidak cukup mengikuti pedoman kualitas, tetapi juga secara konsisten melihat orang lain mengambil tindakan yang berfokus pada kualitas (pola pikir), mendengarkan orang lain berbicara tentang kualitas (pola perilaku), dan merasakan kualitas di sekitar mereka (pola sikap). Kebijakan Nasional Sistem Penjaminan Mutu Pendidikan Tinggi diatur dalam Undang-Undang No. 12 tahun 2012 tentang Pendidikan Tinggi. Penjaminan mutu terdiri dari: Sistem Penjaminan Mutu, Standar Pendidikan Tinggi, Akreditasi, Pangkalan Data Pendidikan Tinggi, dan Lembaga Layanan Pendidikan Tinggi. Kemudian secara teknis diatur dalam Permenristekdikti No. 62 Tahun 2016 tentang Sistem Penjaminan Mutu Pendidikan Tinggi.

Perguruan tinggi secara otonom memiliki hak dan kewajiban melakukan upaya kontrol penyelenggaraan pendidikan dengan menyusun Sistem Penjaminan Mutu Internal (SPMI). Mekanisme implementasi SPMI dilakukan melalui penetapan standar, pemenuhan standar, pembandingan luaran, analisis penyebab standar, serta perbaikan standaryang mengacu kepada SN. Dikti dan Standar Dikti yang telah ditetapkan oleh perguruan tinggi masing-masing. Upaya penjaminan mutu harus dijalankan dan dinilai secara komprehensif, tidak hanya self evaluation, dibutuhkan perspektif lain agar proses kendali melahirkan luaran yang objektif sebagai dasar untuk menjaga serta meningkatkan kinerja penyelenggaraan pendidikan, penelitian, dan pengabdian pada perguruan tinggi. Oleh karena itu, pemerintah 
membentuk Lembaga Akreditasi Mandiri (LAM) dan Badan Akreditasi Nasional Perguruan Tinggi (BAN-PT) untuk melakukan penilaian terhadap kelayakan perguruan tinggi melalui proses akreditasi. Penatalaksanan ini diatur dalam kebijakan Sistem Penjaminan Mutu Eksternal (SPME).

Akreditasi merupakan kegiatan penilaian dalam menentukan kelayakan, baik pada tingkat program studi (APS) maupun institusi (APT). Standardisasi kelayakan akreditasi program studi -IAPS 4.0- terdiri dari 8 (delapan) kriteria, yaitu Tata Pamong, Tata Kelola, dan Kerjasama; Mahasiswa, Sumber Daya Manusia; Keuangan, Sarana dan Prasarana; Pendidikan; Penelitian; Pengabdian kepada Masyarakat; serta Luaran dan Capaian Tridharma. Adapun kriteria untuk penilaian kelayakan perguruan tinggi -AIPT 3.0- terdiri dari 9 (sembilan) kriteria, yaitu Visi, Misi, Tujuan dan Sasaran; Tata Pamong, Manajemen, dan Kerjasama; Mahasiswa; Sumber Daya Manusia; Pengajaran dan Pembelajaran; Keuangan, Aset, dan Fasilitas; Penelitian; Pelayanan Umum; serta Luaran dan Capaian.

Kriteria pada akreditasi merupakan gambaran umum konstruksi sebuah perguruan tinggi dalam konteks manajemen, juga sebagai representasi dari tata kelola kampus yang diturunkan dalam bentuk unit-unit kerja pelaksana akademik dan administratif. Satuan kerja tersebut menjelaskan mengenai apa, siapa, mengapa, dan bagaimana proses penyelenggaraan institusi pendidikan tinggi. Unit akademik berfungsi melaksanakan kegiatan layanandan evaluasi di bidang pendidikan, penelitian, dan pengabdian masyarakat. Sedangkan unit administratif bertugas dalam bidang ketatusahaan, surat menyurat, serta aktivitas administrasi lainnya guna mendukung kelancaran kegiatan tri dharma perguruan tinggi. Pada praktiknya, aktivitas -perguruan tinggi- tersebut dilakukan melalui 2 (dua) cara, yaitu interaksi langsung dan interaksi tidak langsung. Kegiatan interaksi langsung adalah proses manajemen yang dilakukan melalui tatap muka, antara lain rapat, pembelajaran di kelas, penelitian lapangan, kuliah kerja nyata, dan lain-lain. Mempertemukan dua orang atau lebih untuk mencapai tujuan yang telah ditetapkan. Interaksi tidak langsung adalah aktivitas pencapaian tujuan organisasi yang dilaksanakan dengan menggunakan media perantara, antara lain telepon genggam, internet (WAN), pengelolaan database (LAN), dan sebagainya. Kedua aktivitas ini bersifat komplementer dan substitutif, saling melengkapi dan/atau dapat menggantikan fungsi satu sama lain. Misalnya, pembelajaran di kelas dapat digantikan dengan video conference, registrasi mahasiswa dapat menggunakan layanan digital, penyimpanan data kepegawaian dalam aplikasi komputer. 
Pada masa pandemi saat ini, pemerintah mengeluarkan kebijakan physical distancing, yaitu pembatasan jarak fisik antar manusia dalam upaya pencegahan penyebaran virus corona. Frasa ini merupakan revisi dari kebijakan organisasi kesehatan dunia (WHO) yang sebelumnya diberi istilah social distancing, yaitu pembatasan kegiatan masyarakat secara umum. Pengubahan istilah tersebut menegaskan bahwa aktivitas sosial tetap boleh dilakukan dengan memperhatikan protokol kesehatan yang telah ditetapkan pemerintah, yaitu menjaga jarak dalam rentang 1-2 meter antar individu dan maksimal 5-10 orang dalam kegiatan kelompok. Namun agar penyebaran virus terkendali secara efektif, maka pemerintah mengimbau untuk tidak keluar rumah atau tidak melakukan aktivitas tatap muka apabila kegiatan tersebut dianggap masih dapat dilakukan secara virtual. Pengecualian tersebut diberlakukan bagi layanan kesehatan, pertahanan dan keamanan, penyaluran kebutuhan pokok, dan sebagainya. Kegiatan akademik -perguruan tinggi- merupakan salah satu aktivitas yang dilarang karena mengumpulkan massa dalam jumlah yang banyak sehingga berpotensi menyebarkan virus secara cepat (transmisi). Oleh karena itu, segala bentuk aktivitas pembelajaran dan pengelolaan kampus dialihkan dengan menggunakan metode dalam jaringan (virtual) atau saat ini lebih dikenal dengan istilah Work From Home (WFH), bekerja dari rumah.

Untuk menjawab tantangan diatas, dalam rangka menjaga kelangsungan hidup dan mencapai tujuan institusi secara efektif dan efisien, perguruan tinggi harus mampu beradaptasi dengan teknologi. Meskipun harus diakui bahwa kondisi objektif di Indonesia, tiap perguruan tinggi memiliki perbedaan dalam menyetarakan kemampuan operasionalisasi teknologi. Senjang tersebut terdapat pada karakterisitik organisasi, sumber daya, dan kompetensi.Penelitian ini bertujuan untuk mengetahui sejauh mana dan bagaimana menjaga efektifitas kegiatan bekerja dari rumah (work from home) melalui implementasi tata kelola sistem informasi pada perguruan tinggi swasta di Indonesia.

\section{METODE PENELITIAN}

Mengacu pada permasalahan dan tujuan yang hendak dicapai, jenis penelitian yang digunakan adalah penelitian kualitatif dengan pendekatan studi pustaka (library research). Untuk memberikan gambaran dan narasi yang jelas, penulis menggunakan metode analisis deskriptif. Hal ini lebih tepat digunakan karena melihat permasalahan yang diteliti merupakan peristiwa yang sedang berlangsung pada saat ini. Melakukan eksplorasi terhadap fenomena 
yang terjadi dalam bentuk manajemen organisasi, perilaku kerja, dan perilaku manusia dengan memperhatikan karakteristik, varian, korelasi antar kegiatan.

Objektifikasi penelitian kualitatif terdapat pada pengujian data yang dilakukan. Triangulasi data harus dilakukan sedemikan rupa agar keabsahan data terkonfirmasi dengan baik.Data dinyatakan valid jika tidak ada perbedaan yang signifikan antara yang dilaporkan peneliti dengan apa yang sebenarnya terjadi pada objek yang diteliti (Sugiyono, 2016).Peneliti menggunakan data sekunder dari berbagai sumber berupa buku, jurnal ilmiah, peraturan perundangan, artikel, dan literatur lainnya yang menunjang.

\section{PEMBAHASAN}

\section{Organisasi Perguruan Tinggi}

Peraturan Pemerintah No. 4 Tahun 2014 menentukan bahwa penyelenggaraan pendidikan tinggi dilaksanakan oleh suatu organisasi perguruan tinggi yang terdiri atas senat, pemimpin perguruan tinggi, satuan pengawas internal, dan dewan penyantun. Secara umum, unsur-unsur tersebut merepresentasikan fungsi penyusunan kebijakan, pengelolaan, pengawasan, serta pertimbangan, baik ranah akademik maupun non-akademik.

Dalam konteks manajemen, fungsi tata kelola lembaga dilaksanakan oleh pemimpin perguruan tinggi dan merupakan unsur pelaksana akademik yang menjalankan fungsi penetapan kebijakan non-akademik. Pemimpin perguruan tinggi paling tidak terdiri atas:

1. Rektor/Ketua/Direktur. Bertugas memimpin penyelenggaraan pendidikan, penelitian, dan pengabdian kepada masyarakat serta mengelola sumber daya, mahasiswa, dan hubungannya dengan lingkungan.

2. Wakil Rektor/Ketua/Direktur. Bertugas membantu Rektor/Ketua/Direktur dalam memimpin pelaksanaan kegiatan sesuai dengan bidang tugasnya.

\section{Unit Pelaksana Pendidikan}

a. Fakultas. Bertugas menyelenggarakan dan mengelola pendidikan akademik, vokasi, dan/atau profesi dalam satu atau beberapa pohon ilmu pengetahuan dan teknologi.

b. Jurusan. Bertugas menyelenggarakan dan mengelola pendidikan akademik, vokasi, atau profesi dalam 1 (satu) atau beberapa cabang ilmu pengetahuan dan/atau teknologi.

4. Unit Pelaksana Penelitian dan Pengabdian kepada Masyarakat. Bertugas melaksanakan penelitian dan pengabdian kepada masyarakat berbasis ilmu pengetahuan, teknologi 
dan/atau seni untuk menunjang pendidikan, pengembangan institusi, serta pembangunan nasional, wilayah dan/atau daerah.

5. Unit Pelaksana Penjaminan Mutu. Bertugas merencanakan, melaksanakan, mengendalikan, dan mengembangkan sistem penjaminan mutu internal.

6. Unit Pelaksana Administrasi atau Ketatausahaan. Bertugas menyelenggarakan koordinasi pelaksanaan tugas dan layanan administrasi kepada seluruh unit organisasi di lingkungan perguruan tinggi.

7. Unit Penunjang Akademik atau Sumber Belajar. Bertugas mendukung pelaksanaan pendidikan, penelitian, pengabdian kepada masyarakat, dan tata kelola yang tidak dilaksanakan oleh unit organisasi di lingkungan perguruan tinggi.

Berdasarkan uraian diatas, dapat dilakukan pemetaan kelompok kerja sebagai berikut: (1) Penyusun kebijakan; (2) Pelaksana akademik; (3) Pengawas dan penjaminan mutu; (4) Penunjang akademik atau sumber belajar; dan (5) Pelaksana administrasi atau tata usaha. Kelima komponen tersebut mewakili seluruh fungsi manajemen, dimulai dari perencanaan, pengorganisasian, pelaksanaan, hingga pengendalian dan evaluasi dalam lingkup strategis maupun teknis, sejak dari pengambilan keputusan (kebijakan) hingga pemenuhan tugas administratif. Adapun aktivitas organisasi yang melingkupi fungsi manajemen secara holistik direpresentasikan dalam tabel di bawah ini:

\section{Tabel 1.}

\section{Matriks Aktivitas Manajemen Perguruan Tinggi}

\begin{tabular}{|c|c|c|}
\hline $\begin{array}{c}\text { Fungsi } \\
\text { Manajemen }\end{array}$ & Ruang Lingkup & Kegiatan \\
\hline Perencanaan & $\begin{array}{l}\text { Perumusan kebijakan dan } \\
\text { pengambilan keputusan }\end{array}$ & $\begin{array}{l}\text { Rapat pimpinan, rapat kerja, rapat } \\
\text { unit kerja. }\end{array}$ \\
\hline $\begin{array}{l}\text { Pengorganisa } \\
\text { sian }\end{array}$ & $\begin{array}{l}\text { Aktivitas manajerial antar unit kerja, } \\
\text { individu dengan unit kerja, dan } \\
\text { interpersonal }\end{array}$ & $\begin{array}{l}\text { Koordinasipimpinan dengan unit } \\
\text { kerja, koordinasi lintas unit kerja, } \\
\text { koordinasi antar individu }\end{array}$ \\
\hline Pelaksanaan & $\begin{array}{l}\text { Implementasi program kerja di } \\
\text { bidang pendidikan, penelitian, dan } \\
\text { pengabdian kepada masyarakat }\end{array}$ & $\begin{array}{l}\text { Kegiatan belajar mengajar KBM), } \\
\text { seminar, penyusunan jurnal/artikel } \\
\text { ilmiah dan skripsi/skripsi/disertasi, } \\
\text { kuliah kerja nyata, ketatausahaan } \\
\text { (administrasi), kepustakaan, }\end{array}$ \\
\hline
\end{tabular}




\begin{tabular}{|l|l|l|}
\hline & & $\begin{array}{l}\text { penerimaan mahasiswa } \\
\text { baru(promosi) }\end{array}$ \\
\hline $\begin{array}{l}\text { Pengendalian } \\
\text { dan Evaluasi }\end{array}$ & Penjaminan mutu & $\begin{array}{l}\text { Monitoring dan evaluasi program } \\
\text { kerja, pelacakan almuni, survei } \\
\text { kepuasan dan umpan balik }\end{array}$ \\
\hline
\end{tabular}

\section{Transformasi Manual ke Digital}

Secara istilah, manual memiliki arti dilakukan dengan tangan (KBBI, 2008). Makna implisit dari istilah tersebut adalah segala bentuk aktivitas produksi yang dikerjakan oleh manusia tanpa campur tangan aplikasi berbasis komputer ataupun perangkat keras lain yang memanfaatkan internet. Kreasi tersebut menggunakan segala sumber daya alami manusia, berupa organ tubuh dan daya pikir secara murni dan mandiri, tidak dibantu oleh teknologi digital. Manusia menggunakan pertimbangan subjektif (inderawi) dalam pengambilan keputusan yang memiliki dampak sosial ekonomi, misal dalam memberlakukan hukuman dan ganjaran atas kinerja. Keputusan lain yang bertendensi kepada perilaku manusia (karyawan) dibutuhkan treatment khusus. diantaranya melalui pendekatan komunikasi interpersonal.

Pada perguruan tinggi, penelitian kualitatif yang menelaah perilaku manusia dibutuhkan pendekatan khusus yang tidak bisa dijustifikasi oleh kalkulasi angka, rekayasa data, dan kemampuan teknologi komputer lainnya. Salah satu metode yang dilakukan dalam penelitian kualitatif adalah wawancara, merupakan proses tanya jawab yang dilakukan oleh peneliti kepada responden untuk mengidentifikasi karakteristik objek penelitian, dalam hal ini perilaku manusia. Pernyataan yang dikeluarkan oleh responden tidak dapat dianggap benar atau jujur secara langsung. Mimik muka, gestur tubuh, dan konsistensi jawaban dari satu pertanyaan ke pertanyaan yang lain dijadikan pertimbangan untuk menentukan validitas jawaban responden. Demikian pula dalam mengambil kesimpulan atas hasil pembahasan, peneliti harus membandingkan simpul karakterisitik responden yang satu dengan responden lainnya, dengan tujuan meminimalisir kemungkinan penyimpangandan menentukan batas kesalahan (margin eror) dalam melakukan generalisasi.

KBBI mendifinisikan digital sebagai sesuatu yang berhubungan dengan angka-angka untuk sistem perhitungan tertentu; berhubungan dengan penomoran. Sedangkan digitalisasi 
merupakan proses transformasi data menjadi informasi dari format analog (manual) menjadi format digital (komputerisasi) melalui alur penyimpanan, pengelompokkan, pengolahan, dan pendistribusian. Maka secara kontekstual, digital tidak hanya bersifat matematis, perhitungan angka, penyusunan rumus. Lebih dari itu, terdapat perubahan paradigma dan teknis kerja dari manual menjadi proses kerja yang menggunakan media perantara (komputer-internet).

Revolusi industri 4.0 merupakan wujud kemajuan teknologi yang mengintegrasikan dan mensinergikan dunia fisik, biologis, dan digital. Pemerintah melalui Kementerian Pendidikan dan Kebudayaan yang membawahi penyelenggaraan pendidikan tinggi mendorong perguruan tinggi untuk melakukan akselerasi konektivitas pelaksanaan tri dharma perguruan tinggi dengan perkembangan teknologi. Upaya adaptasi terhadap teknologi dilakukan sebagai ikhtiar meningkatkan kualitas pendidikan, penelitian, dan pengabdian kepada masyarakat yang merupakan kewajiban utama bagi perguruan tinggi. Oleh karena itu, optimalisasi tekonologi -informasi- menjadi keniscayaan bagi perguruan tinggi agar tidak tergerus oleh persaingan layanan jasa pendidikan.

Namun dalam implementasinya, pergesaran pola manajemen ini tidak dapat dilaksanakan secara radikal. Dibutuhkan berbagai kebijakan dan kebijaksanaan yang mampu memediasi peran manusia dan mesin. Sehingga tidak menyebabkan dehumanisasi, karena sejatinya revolusi indutri 4.0 bukan soal konvergensi digital atau perkembangan teknologi semata, tetapi mencakup perubahan serta pergeseran seluruh aspek kehidupan manusia. Oleh karena itu, perubahan fundamental terletak pada manusia itu sendiri, sebagai insan "pencipta" dinamika kehidupan di dunia. Pekerjaan organisasi tidak bisa sepenuhnya menggunakan tangan manusia secara murni. Pun sebaliknya, organisasi yang bergantung secara total kepada teknologi komputer belum tentu dapat menyelesaikan pekerjaannya dengan baik menurut kaidah-kaidah tertentu. Paradigma tersebut didasari oleh beberapa asumsi,antara lain sebagai berikut:

\section{Efektivitas.}

Pada hal tertentu, khususnya pengolahan data, manusia memiliki keterbatasan mengolah data yang besar dan kompleks secara manual. Besar diartikan jumlah yang banyak, sedangkan kompleks merupakan data yang secara fungsional memiliki kaitan dengan data lain sehingga simbiosis data tersebut dapat menghasilkan informasi yang utuh. 
Proses pengerjaan manual pada perguruan tinggi yang memiliki jumlah mahasiswa ribuan akan kewalahan tatkala dibutuhkan informasi spesifik mengenai jumlah mahasiswa berdasarkan jenis kelamin, angkatan, jurusan, dan lain sebagainya.

\section{Keamanan Data}

Selain data mahasiswa, setiap perguruan tinggi mempunyai data mengenai dosen, tenaga kependidikan, keuangan, serta aset. Untuk memudahkan transmisi dan penyebaran informasi, data tersebut direkam pada komputer sehingga menjadi basis data. Dengan menggunakan teknologi informasi (software), data tersebut diklasifikasikan berdasarkan unit kerja, diolah menurut kebutuhan serta didistribusikan sesuai dengan peruntukkannya.

3. Pertimbangan Sosial

Manusia tidak bisa hidup sendiri, dia memiliki fitrah untuk berinteraksi sosial (zoon politicon). Interaksi ini bertujuan untuk memenuhi kebutuhan psikologis dan biologis (fisiologis), keamanan, cinta dan kasih sayang, pengakuan, serta aktualisasi diri. Tidak semua aktivitas manajemen perguruan tinggi dapat diselesaikan secara efektif oleh teknologi. Manusia memiliki kekhasan (baca: intuisi) yang menjadi faktor produksi dalam mengolah informasi pada proses pengambilan keputusan. Intuisi tersebut menganalisis gerak tubuh, gaya bahasa, dan bentuk komunikasi verbal maupun komunikasi non verba lainnya.

Pada forum rapat koordinasi kegiatan, terdapat sesi pembagian tugas dan wewenang berdasarkan tugas pokok dan fungsi unit kerja. Forum tersebut terdiri dari proses penyampaian informasi, tukar pendapat, diskusi, dan bermuara pada kesepakatan kerja. Terdapat aktivitas yang bersifat instruktif juga koordinatif. Dimensi instruktif lebih mudah untuk mengendalikan, karena ada level otoritas yang dapat menghakimi kebenaran dan kesalahan yang tidak tertuang secara tersurat dalam aturan kerja. Sedangkan wilayah koordinatif rentan ketidaksepahaman yang berujung tersendatnya pencapaian tujuan. Dibutuhkan kepercayaan, kejujuran, keterbukaan, serta pemahaman terhadap substansi pekerjaan. Untuk mengukur ranah tersebut, manusia mengamati perilaku manusia lainnya (rekan kerja). Melihat rekam jejak perilaku individu, konsistensi dalam melaksanakan kewajibannya, bahkan menilai dari gestur fisik rekan kerjanya. Keseluruhan mekanisme intuitif tersebut tidak dapat digantikan oleh komputer yang hanya mampu mengolah data menurut prosedur yang telah dirumuskan dan bersifat final (kaku). 


\section{Tata Kelola Sistem Informasi}

Sistem informasi merupakan integrasi teknologi informasi dengan pengguna teknologi tersebut untuk mendukung kinerja manajemen. Teknologi informasi pada perguruan tinggi akan berdaya apabila disertai dengan kebijakan yang dapat meningkatkan operasionalisasi peran dan fungsi teknologi informasi itu. Koherensi teknologi, unit kerja, sumber daya manusia, dan peraturan hendaknya dilakukan secara konsisten. Dibutuhkan kesadaran manajemen bahwa pada tiap-tiap komponen tersebut terdapat hubungan sistemik. Berjalannya fungsi suatu komponen akan berpengaruh terhadap efektivitas kerja komponen lainnya. Begitu pula sebaliknya, matinya peran satu unsur saja akan berimbas pada kejumudan sistem informasi. Pemanfaatan teknologi informasi pada perguruan tinggi umumnya digunakan untuk mendukung aktivitas yang bersifat administratif, seperti adminitrasi di bidang akademik, bidang kepegawaian, dan bidang keuangan. Meskipun seharusnya, pemanfaatan sistem informasi yang tepat guna dan tepat sasaran dapat menunjang proses-proses eksekutif, misal penyusunan kebijakan dan pengambilan keputusan. Secara holistik, manfaat teknologi informasi bagi perguruan tinggi dapat dikategorikan menjadi dua peranan, yaitu peranan utama dan peranan penunjang. Peranan utama teknologi informasi dalam proses pembelajaran, terdiri dari pendukung aktivitas belajar mengajar, pemberdaya dosen dan mahasiswa, alat kelola aset intelektual, penunjang kegiatan penelitian, serta pengembangan produk pendidikan. Peranan penunjang teknologi informasi dalam penyelenggaraan institusi terdiri dari pendukung kegiatan administrasi dan operasional, membantu high level managerial dalam pengambilan keputusan, mendukung komunikasi antar pemangku kepentingan (stakeholders), menjamin optimalisasi sumber daya dan proses, serta menjalin kemitraan strategis dengan pihak eksternal (Indrajit, 2011)

Sepintas dapat kita lihat, optimalisasi teknologi informasi telah dilaksanakan dengan konsisten dan berkelanjutan. Tiap perguruan tinggi memiliki situs web, sistem informasi akademik dan keuangan, aplikasi pengelolaan data kepegawaian, pembelajaran dalam jaringan (e-learning). Tidak sedikit pula, perguruan tinggitelah membangun infrastruktur teknologi informasi berbasis backbone dengan menggunakan fiber optik untuk meningkatkan kecepatan serta stabilitas interkoneksi, transformasi, distribusi, security dan lalu lintas data. Namu pada kenyataannya, komponen-komponen pendukung itu tidak dilakukan secara optimal. Pemanfaatan sistem informasi dan jaringannya hanya menyentuh wilayah permukaan saja, tidak dapat menembus substansi sasaran yang seharusnya, sehingga 
kemanfaatannya berlaku di tataran teknis operasional, belum dapat mendukung perencanaan strategis.Permasalahan implementasi sistem informasi pada perguruan tinggi dapat dirangkum dalam kelompok berikut, antara lain

1. Tidak terdapatnya rencana strategis pengembangan teknologi informasi. Rencana pengembangan TI merupakan peta koneksi implementasi teknologi informasi terhadap capaian visi, misi, sasaran, dan program perguruan tinggi.

2. Tidak adanya unit kerja khusus yang mengelola dan mengembangkan teknologi informasi, sehingga menyebabkan ketidakjelasan penanggungjawab dan pelaksana kegiatan.

3. Ketidakjelasan standar operasional prosedur (SOP).

Kasus-kasus yang terjadi biasanya diatasi secara insidental dan parsial, sehingga penyelesaiannya tidak tuntas dan memungkinkan persoalan baru yang hampir serupa di waktu yang akan datang. Pembiaran hal ini akan menjadi bom waktu bagi manajemen teknologi informasi pada khususnya, dan tata kelola perguruan tinggi pada umumnya.

Potret kondisi objektif tata kelola teknologi informasi diatas mengharuskan adanya evaluasi secara komprehensif, baik dari segi teknis maupun non-teknis dengan menyusun indikator-indikator kinerja teknologi informasi. Domain teknis membahas mengenai aspek teknis seperti ketercukupan dan ketersediaan sarana prasarana teknologi informasi (perangkat lunak maupun perangkat keras). Domain non-teknis mencakup aspek-aspek lainnya seperti kebijakan tata laksana TI, tingkat pemahaman dan pengetahuan teknologi informasi (IT literacy), penerimaan dan kesadaran terhadap teknologi informasi (IT awareness and acceptance), kelembagaan TI, dan praktek tatakelola TI (IT governance) (Nugroho, 2009).

Tabel 2.

Evaluasi Kondisi Objektif Teknologi Informasi

\begin{tabular}{|c|l|l|l|}
\hline No & \multicolumn{1}{|c|}{ Aspek } & \multicolumn{1}{|c|}{ Keterangan } & \multicolumn{1}{c|}{ Indikator Kinerja } \\
\hline 1 & Komputer kerja & - Desktop stations yang & - Tersedianya komputer (CPU) \\
& dan Komputer & digunakan untuk & kebutuhan aplikasi perkantoran \\
& \multirow{2}{*}{ akses jaringan } & keperluan administratif & - Tersedianya desktop (PC) atau laptop \\
& & - Terminal akses WAN & untuk keperluan pengelolaan sistem \\
& & maupun LAN & informasi \\
\hline 2 & Koneksi internet & Perangkat internet, & - Tersedianya acces point, router, port \\
& & kapasitas bandwidth, & USB, dan Wireless Network Adapter \\
& & utilitas & - Kapasitas bandwidth yang memadai \\
\hline
\end{tabular}


Danial Kusumah, Sinta Maria Dewi

Vol. 5 No 2

ISSN : 2541-6995

E ISSN : 2580-5517

\begin{tabular}{|c|c|c|c|}
\hline & & & $\begin{array}{l}\text { - Kualitas koneksi } \\
\text { - Pembagian transmisi internet }\end{array}$ \\
\hline 3 & Server & $\begin{array}{l}\text { Perangkat keras yang } \\
\text { berfungsi sebagai pusat } \\
\text { data }\end{array}$ & $\begin{array}{l}\text { Kualitas processor, besaran memory, } \\
\text { cache, dan teknologi yang mendukung } \\
\text { kestabilan }\end{array}$ \\
\hline 4 & Jaringan lokal & $\begin{array}{l}\text { Aksesibiltas komputer } \\
\text { pada wilayah jaringan } \\
\text { terbatas (lokal) }\end{array}$ & $\begin{array}{l}\text { Infrastruktur backbone dan } \\
\text { penggunaan fiber optik }\end{array}$ \\
\hline 5 & Aplikasi & $\begin{array}{l}\text { Pemanfaatan aplikasi } \\
\text { yang menunjang } \\
\text { kegiatan informatif, } \\
\text { administratif dan } \\
\text { akademik }\end{array}$ & $\begin{array}{l}\text { Tersedianya situs web, sistem } \\
\text { informasi akademik, keuangan, } \\
\text { kepegawaian, aset, dan aplikasi } \\
\text { perkantoran }\end{array}$ \\
\hline 6 & $\begin{array}{l}\text { SDM teknologi } \\
\text { informasi }\end{array}$ & $\begin{array}{l}\text { Pengelola teknologi dan } \\
\text { sistem informasi }\end{array}$ & $\begin{array}{l}\text { Ketersediaan progamer, teknisi, dan } \\
\text { operator untuk menunjang pelaksanaan } \\
\text { dan pelayanan program }\end{array}$ \\
\hline 7 & Kelembagaan TI & $\begin{array}{l}\text { Satuan kerja formal } \\
\text { untuk operasionalisasi TI }\end{array}$ & $\begin{array}{l}\text { Tersedianya unit kerja khusus yang } \\
\text { bertanggung jawab atas pengelolaan TI }\end{array}$ \\
\hline 8 & Tata kelola TI & $\begin{array}{l}\text { Kebijakan terkait } \\
\text { penyelenggaraan } \\
\text { teknologi informasi }\end{array}$ & $\begin{array}{l}\text { Tersedianya manual mutu dan SOP } \\
\text { pengelolaan teknologi informasi }\end{array}$ \\
\hline 9 & $\begin{array}{l}\text { Penerimaan dan } \\
\text { kesadaran }\end{array}$ & $\begin{array}{l}\text { Perilaku (kesadaran), } \\
\text { penerimaan, dan cara } \\
\text { pemanfaatan teknologi } \\
\text { informasi oleh pengguna }\end{array}$ & $\begin{array}{l}\text { Luaran dan/atau dampak penggunaan } \\
\text { TI }\end{array}$ \\
\hline
\end{tabular}

Agar implementasi penyelenggaraan teknologi dan sistem informasi pada perguruan tinggi berjalan efektif dan efisien maka pelaksanaanya harus mengacu pada prinsip kemudahan penggunaan (user friendly), keterpenuhan dan kecepatan akses, paperless, integratif, inovatif, serta berbiaya murah. Upaya mitigasi dari kemungkinan timbulnya dampak tidak diharapkan yang berpotensi menghambat pencapaian tujuan dalam perencanaan program-program, perguruan tinggi sebaiknya merumuskan rencana kontingensi, yaitu, 
antisipasi kemungkinan munculnya kondisi-kondisi yang tidak terprediksikan. Selanjutnya menentukan langkah-langkah teknis dan strategis guna meminimalisir efek negatif terhadap pelaksanaan program.

\section{Implementasi Sistem Informasi}

Salah satu upaya pemerintah dalam rangka percepatan penangan dan pencegahan penyebaran Covid-19 adalah dengan menetapkan peraturan mengenai Pembatasan Sosial Berskala Besar (PSBB). Pasal 4 Peraturan Pemerintah Nomor 21 Tahun 2020 menjelaskan ruang lingkup pembatasan dan/atau pelarangan beberapa kegiatan antara lain peliburan sekolah dan tempat kerja. Peliburan sekolah yang dimaksud adalah pemberhentian kegiatan belajar mengajar (KBM) sekolah/perguruan tinggi dengan mengalihkan proses belajar mengajar tata muka di kelas ke pembelajaran di rumah dengan memanfaatkan teknologi informasi. Sementara peliburan tempat kerja merupakan pembatasan segala aktivitas di tempat kerja dengan proses bekerja di tempat tinggal masing-masing (rumah) demi menjaga kelangsungan operasional institusi atau perusahaan. Aktivitas pendidikan, penelitian, pelatihan, pengabdian yang berhubungan dengan pelayanan kesehatan dapat dikecualikan. Merujuk pada penjelasan tersebut, seluruh perguruan tinggi tidak diperbolehkan untuk melaksanakan KBM, namun masih dapat melakukan layanan administratif dengan tetap memenuhi protokol kesehatan. Agar pencegahan penularan virus terkendali secara efektif, maka setiap aktivitas berupa KBM beserta pekerjaan administratifnya diimbau untuk dialihkan kepada layanan yang bersifat virtual dengan memanfaatkan teknologi informasi pada perguruan tinggi.

Bagi perguruan tinggi negeri (PTN), pengalihan metode manual ke digital ini cenderung tidak akan menimbulkan masalah yang signifikan. Dalam hal penyelenggaraan kegiatan akademik dan administrasinya, PTN mendapat dukungan penuh dari pemerintah melalui kebijakan anggaran beserta instrumen pendukung lainnya. Sedangkan untuk perguruan tinggi swasta yang bergerak mandiri, mereka dihadapkan pada realitas keterbatasan kemampuan terkait optimalisasi pemanfaatan teknologi informasi guna mendukung penyelenggaraan aktivitas manajemen.

Terkait urusan anggaran untuk memenuhi kebutuhan teknologi yang mendorong lancarnya roda sistem informasi, PTS hendaknya kreatif untuk mencari dana pihak eksternal dari pemerintah berupa hibah kompetitif, dana CSR perusahaan, serta pendayagunaan 
pendapatan dari unit usaha bidang ekonomi. Adapun pada wilayah penatalaksanaannya, perguruan tinggi swasta dituntut untuk lebih kreatif, inovatif, terutama meningkatkan kesadaran organisasi dan sivitas akademiknya untuk menyusun rencana strategis dan pengaturan operasional implementasi sistem informasi.

Matriks aktivitas manajemen perguruan tinggi yang dituangkan dalam tabel 1.pada tahap ini dijadikan acuan untuk menganalisis kebutuhan dan implementasi sistem informasi dalam penyelenggaraan aktivitas manajemen perguruan tinggi. Kerangka berpikir yang digunakan dalam analisis ini adalah pergeseran paradigma manual ke digital yang dapat diterapkan oleh perguruan tinggi swasta -khususnya- sebagai upaya adaptif terhadap kebijakan pemerintah terkait pembatasan kegiatan lembaga pendidikan pada masa pandemi covid-19. Kebijakan percepatan penanganan wabah corona ini tidak hanya mengubah proses teknis aktivitas, juga mengubah lokasi pelaksanaan kegiatan yang semula dikerjakan di kantor menjadi pekerjaan yang dilaksanakan di rumah (work from home) Proposisi atas kebutuhan sistem informasi menggunakan pendekatan standar minimum kemampuan perguruan tinggi swasta pada umumnya melalui proses triangulasi yang mengacu pada diseminasidata dari pemerintah, informasi dari website perguruan tinggi swasta, publikasi jurnal ilmiah, dan lain sebagainya. Untuk mewujudkan kondisi ideal kemanfaatan teknologi informasi pada perguruan tinggi, dibutuhkan pengembangan dan pengadaan aplikasi pendukung sistem informasi perguruan tinggi yang dilaksanakan melalui 4 (empat) tahapan, yaitu penyajian informasi (publish), interaksi, transaksi, dan interkoneksi antar sistem. Diharapkan, penggunaan aplikasi-aplikasi tersebut dapat mendukung efektivitas dan produktivitas penyelenggaraan fungsi manajemen.

\section{Fungsi Perencanaan}

a. Ruang lingkup: Perumusan kebijakan dan pengambilan keputusan

b. Kegiatan: Rapat pimpinan, rapat kerja, rapat unit kerja.

c. Kebutuhan sistem informasi (aplikasi)

Perumusan Kebijakan dan Pengambilan Keputusan.

Perumusan kebijakan dan pengambilan keputusan merupakan forum deliberatif. Aktivitas didalamnya dapat berupa tukar pendapat, ide, gagasan, penyampaian informasi, pembasahan teknis kerja, serta pengambilan keputusan. Salah satupendekatan yang efektif digunakan adalah metode teleworkingberupa video 
conference, yaitu teknologi komunikasi yang memungkinkan terlaksananya komunikasi interpersonal maupun kelompok pada lokasi yang berbeda secara simultan dengan menampilkan video dan audio (suara). Terdapat banyak aplikasi berbayar maupun gratisan dengan mempertimbangkan kestabilan jaringan untuk meminimalisir distorsi dalam komunikasi, antara lain google hangouts meet, zoom meeting, microsoft teams. Secara teknis, aplikasi-aplikasi tersebut memiliki keunggulan dalam bentuk user interface yang sederhanadan baik sehingga mudah untuk digunakan. Selain dapat diaplikasikan pada perangkat komputer, perangkat lunak ini kompatibel dengan smartphone, sehingga fleksibel untuk proses koordinasi bagi pengguna yang sedang berada di lapangan dan sulit mengakses komputer.

\section{Sistem Penganggaran.}

Salah satu pembeda antara insitusi pendidikan tinggi dengan pemerintah dan perusahaan pada umumnya adalah penetapan waktu tahun anggaran. Lazimnya, institusi non pendidikan tinggi memulai tahun anggaran di bulan januari dan menutup buku pada bulan desember (akhir tahun). Sedangkan tahun anggaran pada perguruan tinggi menyesuaikan tahun anggaran dengan tahun ajaran yang berbasis kalender akademik, yaitu jadwal pelaksanaan kegiatan akademik dalam jangka waktu satu tahun. Pada umumnya, perguruan tinggi menetapkan tahun ajaran baru antara pertengahan agustus sampai dengan awal september. Integrasi data akademik untuk seluruh perguruan tinggi (PTU dan PTKI) melalui perangkat yang disiapkan oleh Kemenristekdikti beberapa tahun lalu -di PTS- berupa Pangkalan Data Pendidikan Tinggi (PD. Dikti) yang mewajibkan perguruan tinggi untuk melakukan pelaporan penyelenggaraan kegiatan akademik menjadi salah satu pertimbangan kesamaan penetapan awal tahun ajaran. Pandemi covid-19 di Indonesia memang belum menunjukkan kondisi membaik, namun perguruan tinggi negeri dan swasta melalui organisasi koordinasi perguruan tinggi telah menyepakati pelaksanaan tahun ajaran 2020/2021 sesuai dengan kalender akademik yang telah ditetapkan oleh masingmasing perguruan tinggi. Kesepakatan tersebut mempertimbangkan potensi penambahan biaya operasional yang selama ini menurun, sedangkan penerimaan mahasiswa baru menjadi salah satu indikator sumber keuangan perguruan tinggi. Memperhatikan hal tersebut, dalam hal penyusunan rencana kerja dan anggarannya, 
perguruan tinggi dapat memanfaatkan sistem informasi penganggaran (SIP) berbasis web. Mekanisme SIP diawali dengan pengajuan rencana kerja dan anggaran oleh tiap unit kerja. Data ajuan diintegrasikan dan diklasifikasikan berdasarkan satuan kerja. Selanjutnya, dilakukan proses penelaahan oleh Rektor/Ketua/Direktur perguruan tinggi untuk kemudian direvisi agar diperbaiki lalu disetujui. Proses realisasi penggunaan dan pelaporan dipantau oleh sebuah fitur monitoring statistik.

\section{Fungsi Pengorganisasian}

a. Ruang Lingkup: Aktivitas manajerial antar unit kerja, individu dengan unit kerja, dan interpersonal.

b. Kegiatan: Koordinasi pimpinan dengan unit kerja, koordinasi lintas unit kerja, koordinasi antar individu.

c. Kebutuhan sistem informasi.

Koordinasi merupakan proses manajerial yang berfungsi memberikan informasi, menyamakan persepsi, dan mendelegasikan wewenang. Fungsi koordinasi biasanya efektif dilakukan dengan metode luring (luar jaringan/offline) agar informasi yang diterima tersampaikan secara utuh dan jelas. Namun melalui penggunaan sistem informasi yang dibangun dengan baik, gangguan komunikasi yang menghambat pencapaian tujuan dapat diatasi. Lebih dari itu, penggunaan sistem informasi dapat memangkas waktu dan birokrasi.

Disposisi merupakan salah satu instrumen koordinasi yang berisi instruksi, petunjuk, saran, dan tanggapan atas surat yang masuk kepada lembaga. Dibuat oleh pimpinan untuk ditindaklanjuti oleh bawahan sesuai dengan unit kerja yang relevan dan kompetensi pegawai. Pada lingkungan kampus, kegiatan surat-menyurat, termasuk disposisi di dalamnya, memiliki intensitas yang tinggi, sehingga diperlukan sebuah prosedur yang diadopsi ke dalam sebuah sistem informasi untuk dapat memastikan lalu lintas persuratan berjalan secara efektif. E-disposisi atau disposisi elektronik dapat dijadikan solusi menghadapi dinamika surat menyurat yang terjadi pada perguruan tinggi. 
Alur e-disposisi dimulai dengan kegiatan administrasi pengajuan surat masuk melalui aplikasi yang tersedia untuk diteruskan ke bagian kesekretariatan. Sekretariat memproses dengan melakukan kodefikasi, indeks, dan penomoran yang telah disediakan fitur dalam aplikasi sesuai jenis surat, unit kerja yang membidangi, serta pejabat yang berwenang. Pimpinan atau pejabat berwenang melakukan verifikasi (approving), kemudian memberikan catatan, tanggapan, dan arahan serta diteruskan kepada unit kerja yang membidanginya. Dengan mekanisme digital seperti ini, aktivitas persuratan dapat dilakukan kapanpun dan dimanapun.

\section{Fungsi Pelaksanaan/Aktualisasi}

a. Ruang Lingkup: Implementasi program kerja dan/atau agenda di bidang pendidikan, penelitian, dan pengabdian kepada masyarakat.

b. Kegiatan: Kegiatan belajar mengajar (KBM), seminar, penyusunan jurnal/artikel ilmiah dan skripsi, kuliah kerja nyata, ketatausahaan (administrasi), kepustakaan, penerimaan mahasiswa baru (promosi).

c. Kebutuhan sistem informasi.

\section{E-Learning}

EdLink, Clasroom, Google for Education, dan ragam aplikasi pembelajaran lainnya dapat menjembatani kebutuhan pembelajaran daring (e-learning) bagi perguruan tinggi. Platform ini disediakan secara gratis oleh pengembangnya. Pengguna cukup bermodal akses internet dan gadget untuk dapat mengoperasikan aplikasi tersebut. Aplikasi-aplikasi pembelajaran daring tersebut menyediakan kebutuhan administrasi akademik dan teknis kegiatan belajaran mengajar. Tersedia menu-menu yang berfungsi mengelola absen, pembagian mata kuliah dengan kelasnya, percakapan, video conference, serta fitur unggah dan unduh materi kuliah.

\section{Seminar Online (Webinar)}

Seminar merupakan forum diskusi akademik untuk membahas sebuah topik masalah dan merumuskan solusi penyelesaian masalah tersebut. Bagi perguruan tinggi 
selaku institusi pendidikan, seminar merupakan satu dari banyak kewajiban akademik lainnya yang harus diselenggarakan dalam konteks pengembangan keilmuan dan pengabdian kepada masyarakat. Agar tetap terselenggaranya seminar di tengah pelarangan aktivitas massal secara terbuka, perguruan tinggi dapat mengubah metode tatap muka dengan metode online (Webinar). Salah satu media online yang kerap digunakan oleh instansi pemerintah maupun swasta untuk menyelenggarakan seminar, baik di bidang pendidikan maupun non-kependidikan adalah aplikasi Zoom.

Zoom adalah aplikasi digital yang memberikan layanan konferensi video berbasis komputasi awan (cloud computing). Aplikasi ini memfasilitasikomunikasi virtual dua orang atau lebih dalam bentuk audio visual (suara dan video). Zoom memberikan kemudahan lainnya berupa fasilitas rekaman video dan suara sebagai pengganti notulensi yang lazimnya dilakukan secara manual.

\section{E-Office}

Berbeda dengan disposisi online, e-office merupakan bangunan besar ketatausahaan yang membantu menggantikan proses administrasi yang bersifat manual menjadi metode digital dengan memanfaatkan fasilitas internet dan jaringan komputer.E-office menyediakan derivasi aplikasi antara lain, data akademik, tata naskah (persuratan), kepegawaian, kehadiran, hingga keuangan. Secara teknis, dilengkapi fitur agenda individu, percakapan, shoutbox, dan notifikasi. Adapun sistem informasi yang menjadi turunan dari e-office dapat dijelaskan pada tabel dibawah ini:

\section{Tabel 3.}

\section{Jenis dan Fungsi}

Aplikasi Perkantoran Elektronik (e-office) pada Perguruan Tinggi

\begin{tabular}{|c|l|l|l|}
\hline No. & Jenis Aplikasi & \multicolumn{1}{|c|}{ Fungsi } & \multicolumn{1}{c|}{ Modul } \\
\hline 1 & Sistem Informasi & Pengelolaan data akedemik & - Register nomor identitas \\
& Akademik & untuk mendukung & perguruan tinggi dan \\
& (Siakad) & penyelenggaraan pendidikan & program studi \\
& & & - Data Mahasiswa dan Dosen \\
& & & - Pengajuan KRS \\
& & & - Aktivitas akademik \\
\hline
\end{tabular}


Danial Kusumah, Sinta Maria Dewi

Vol. 5 No 2

ISSN : 2541-6995

E ISSN : 2580-5517

\begin{tabular}{|c|c|c|c|}
\hline & & & $\begin{array}{l}\text { - Sebaran kurikulum } \\
\text { - Jadwal dan absensi kuliah } \\
\text { - Data Nilai }\end{array}$ \\
\hline 2 & $\begin{array}{l}\text { Sistem Informasi } \\
\text { Keuangan } \\
\text { (SimKeu) }\end{array}$ & $\begin{array}{l}\text { Perencanaan, pengelolaan, } \\
\text { dan pengalokasian } \\
\text { (distribusi) anggaran }\end{array}$ & $\begin{array}{l}\text { - Rencana kerja anggaran } \\
\text { - Layanan pembayaran } \\
\text { - Arus kas } \\
\text { - Laporan keuangan } \\
\text { - Penggajian }\end{array}$ \\
\hline 3 & $\begin{array}{l}\text { Sistem Informasi } \\
\text { Kepegawaian } \\
\text { (SimPeg) }\end{array}$ & $\begin{array}{l}\text { Manajemen sumber daya } \\
\text { manusia }\end{array}$ & $\begin{array}{l}\text { - Rekrutmen pegawai } \\
\text { - Promosi, rotasi, dan mutasi } \\
\text { - Kenaikan golongan } \\
\text { - Biodata SDM } \\
\text { - Tupoksi unit kerja dan } \\
\text { pegawai } \\
\text { - Penilaian kinerja } \\
\text { - Finger Print/kehadiran }\end{array}$ \\
\hline 4 & $\begin{array}{l}\text { Sistem Informasi } \\
\text { Manajemen } \\
\text { Inventory }\end{array}$ & $\begin{array}{l}\text { Pengelolaan sarana dan } \\
\text { prasarana (sarpras) } \\
\text { perguruan tinggi }\end{array}$ & $\begin{array}{l}\text { - Kodefikasi sarpras } \\
\text { - Penyusutan nilai sarpras } \\
\text { - Manajemen penempatan } \\
\text { sarpras } \\
\text { - Laporan data sarpras } \\
\text { - Statistik sarpras }\end{array}$ \\
\hline
\end{tabular}

\section{Perpustakaan Digital}

Pemanfaatan teks secara elektronik menunjukkan tren yang meningkat bersamaan dengan euforia revolusi digital di seluruh belahan dunia. Perguruan tinggi sebagai pabrikasi keilmuan harus mampu menyediakan literatur yang dapat dengan mudah diakses oleh dosen, mahasiswa, dan publik melalui jejaring internet. Oleh karena itu, unit penunjang pendidikan berupa perpustakaan harus di-upgrade fungsi, substansi, hingga produknya, menyelerasakan dengan perkembangan teknologi informasi dan berubah wujud menjadi perpustakaan digital. Manfaat yang dapat diambil dengan pengaplikasian perpustakaan digital antara lain mengatasi keterbatasan 
waktu dan tempat, kecepatan memperoleh informasi terkini, kemudahan akses literatur dari berbagai sumber, serta mempermudah perubahan bentuk dan pemindaian teks. Gimik pemasaran dalam rupa open source yang diterapkan oleh pengembang aplikasi sistem informasi dapat dijadikan peluang oleh perguruan tinggi swasta kecil untuk diadopsi dan diubahsuaikan dengan kebutuhan internal kampus. Meskipun akan ditemukan berbagai keterbatasan, namun secara substansial dapat memenuhi kebutuhan umum layanan kepustakaan. Substansi layanan umum terangkum dalam fitur katalog (buku, skripsi, tesis, disertasi, prosiding, jurnal dan artikel ilmiah), sumber literatur eksternal, dan administrasi kepustakaan.

\section{Penerimaan Mahasiswa Baru (PMB) Online}

Penerimaan mahasiswa baru merupakan ujung tombak kesinambungan manajemen perguruan tinggi. Kegiatan ini dapat dijadikan tolok ukur keberhasilan penyelenggaraan pendidikan tinggi pada suatu kampus. Fluktuasi jumlah mahasiswa baru merupakan salah satu indikator untuk mengukur animo masyarakat. Adapun animo masyarakat terhadap perguruan tinggi adalah cerminan persepsi publik atas prestasi institusi dari segi kinerja organisasional, operasional, maupun personal yang memuat capaian akademik dan non-akademik sebuah perguruan tinggi. Akselerasi promosi penerimaan mahasiswa baru dapat dilakukan melalui pendayagunaan media sosial dan optimalisasi fungsi website kampus. Secara statistik, platform yang menjadi primadona pengguna media sosial adalah youtube (88\%), Whatsapp (84\%), Facebook $(82 \%)$,dan terakhir Instagram $(72 \%)$. Durasi akses rata-rata pengguna sosial berada pada kisaran 3,5 jam per hari, dan 99\% menggunakan telepon seluler (Jayani, 2020). Melihat dinamika tersebut, maka media sosial dapat dijadikan instrumen penunjang efektif untuk kegiatan promosi institusi, khususnya untuk kegiatan penerimaan mahasiswa baru. Berdasarkan sebaran jangkauan, biaya akses, serta usia produktif pengguna sosial media, Facebook dan Instagram menjadi aplikasi paling fisibel untuk digunakan dalam meraih pasar potensial yang lebih luas. Pengelolaan database PMB sebaiknya dilakukan satu pintu, yaitu melalui server yang bekerja di dalam sistem website kampus, sehingga integrasi dan pengolahan data lebih mudah untuk dilakukan.

4. Fungsi Pengendalian dan Evaluasi

a. Ruang Lingkup: Monitoring, evaluasi, dan penjaminan mutu. 
b. Kegiatan: Monitoring dan evaluasi program kerja, pelacakan almuni, survei kepuasan dan umpan balik.

c. Kebutuhan sistem informasi.

\section{E-Monev}

Monitoring dan Evaluasi Elektronik (e-monev) adalah sebuah sistem informasi yang berfungsi melakukan pemantauan, evaluasi, dan pelaporan capaian kinerja. Pengukuran yang dilakukan meliputi unsur-unsur: (1) Nilai absolut, parsial, dan kumulatif; (2) Status pelaksanaan; (3) Permasalahan; (4) Bukti pendukung; (5) Kinerja Pelaksanaan; (6) Pelaporan. Justifikasi nilai atas capaian kinerja berbasis kepada standar akreditasi yang telah ditetapkan oleh BAN-PT sehingga memenuhi kaidah link and match antara penilaian kinerja internal dengan standar kelayakan eksternal.

\section{Pelacakan Alumni}

Kegiatan penelusuran alumni dilakukan untuk mengidentifikasi profil lulusan berdasarkan linieritas keilmuan dengan bidang yang digelutinya di tempat bekerja, sekaligus sebagai proses awal penyusunan database alumni. Alat/instrumen yang digunakan untuk melacak profil alumni adalah kuesioner, yaitu sejumlah pertanyaan yang bertujuan untuk mengumpulkan informasi mengenai responden (alumni) yang disesuaikan dengan kebutuhan database alumni. Untuk mengetahui keberadaan alumni, perguruan tinggi melalui pusat kemahasiswaan dan alumni atau unit kerja yang memiliki kesamaan karakteristik fungsional pada perguruan tinggi lainnya mengacu pada database mahasiswa dengan konten by name, by address, by email, dan by phone. Kuesioner yang telah disusun kemudian disebar via email, whatsapp, atau dengan membuat google form, sehingga perolehan data dapat terintegrasi langsung dengan sistem infromasi/database alumni melalui portal khusus atau dirangkum dalam server yang mengelola website, sehingga dapat menjadi bagian dari transparansi dan akuntabilitas kinerja insitusi.

\section{Survei Kepuasan dan Umpan Balik Mahasiswa, Dosen, serta Pengguna Lulusan}

Untuk mengetahui persepsi dosen dan mahasiswa terhadap layanan institusi juga kesesuaian ekspektasi mahasiswa terhadap dosen dari segi kompetensi, linieritas bidang kelimuan, serta perilaku akademik tenaga pendidik, dibutuhkan sebuah survei yang sistematis, terstruktur, dan berkelanjutan. Kegiatan ini dimulai dengan pengumpulan informasi atas kepuasan mahasiswa dan dosen, ditindaklanjuti dengan proses analisa dan evaluasi, lalu dirumuskan rekomendasi sebagai umpan balik bagi kegiatan perencanaan 
pembelajaran di masa yang akan datang. Secara praktis, metode yang digunakan tidak jauh berbeda dengan metode pelacakan alumni. Sedangkan kegiatan survei pengguna lulusan dilaksanakan untuk mengukur sejauh mana peran lulusan dalam mengimplementasikan potensi dirinya di tempat mereka bekerja. Indikator yang digunakan dalam survei kepuasan pengguna lulusan adalah integritas, profesionalitas, kompetensi linguistik, kemampuan menggunakan teknologi informasi, kemampuan berkomunikasi, kerjasama kelompok (tim), dan pengambangan diri. Secara metodologi, teknis survei yang diterapkan sama dengan teknik pada survei kepuasan dan umpan balik mahasiswa dan dosen.

\section{EfektivitasWork From Home}

Istilahopen workspace atau yang lebih dikenal dengan work from home (WFH) bekerja dari rumah- di masa pandemi covid-19 saat ini bukan merupakan hal baru di dunia, termasuk di Indonesia. Konsep ini didasari pada kesadaran yang memberikan pandangan bahwa lingkungan kerja bersifat dinamis -berubah- (agile environment), konotasi pekerjaan lebih mengarahpada aktivitas (kegiatan) daripada ruang (tempat) untuk bekerja. Setiap orang dapat bekerja dimana dan/atau darimana saja, tidak dibatasi spesisifikasi ruangan kerja (remote working). Sektor yang dominan menerapkan konsep WFH ini adalah industri startup yang aktivitas operasional perusaahannya memanfaatkan internet sebagai instrumen penunjang utama. Salah satu jenis startup adalah marketplace, yaitu situs web atau apalikasi online (e-commerce) yang memfasilitasi transaksi jual beli dari berbagai produsen (penjual) kepada konsumen (pembeli).

Terdapat beberapa sisi positif dengan diterapkannya metode bekerja dari rumah. Pertama, penurunan biaya operasional. Aktivitas keseharian perusahaan pada era teknologi informasi ini banyak menggunakan komputer dalam menyelesaikan pekerjaannya. Dengan bekerja dari rumah, perusahaan dapat menekan biaya internet dan listrik. Kedua, fleksibiltas dalam bekerja. Karyawan dapat menyesuaikan kebiasaan kerjanya dari segi waktu, tempat bekerja, dan bahkan pakaian yang mereka gunakan. Keluwesan ini dalam sudut pandang psikoanalisis dapat mengurangi tingkat kejenuhan, sehingga karyawan lebih produktif dalam bekerja. Ketiga, meningkatnya work life balance. Merupakan keseimbangan antara kehidupan kerja, keluarga (pribadi), sosial, dan spiritual. Melalui keseimbangan dalam berbagai aspek kehidupan, manusia akan merasa dirinya lebih bermakna, tidak hanya mampu memenuhi kepuasan lahiriah (materil), juga dapat menjaga terpenuhinya kebutuhan religius, waktu 
untuk membina rumah tangga, serta terpeliharnya hubungan sosial di luar lingkungan kerja. Hal ini menjadi daya ungkit manusia dalam meningkatkan etos kerjanya.

Tidak dapat kita pungkiri, bekerja dari rumah bisa menimbulkan efek negatif. Pertama, kesulitan mengontrol karyawan. Kecenderungan karyawan untuk aktif dalam bekerja biasanya ditentukan oleh proses monitoring yang dilakukan, secara langsung maupun dengan media perantara (alat elektronik). Budaya organisasi dan gaya kepemimpinan berpengaruh dalam membangun kesadaran diri dari tiap-tiap individu ketika menunaikan kewajiban pekerjaannya. Kedua, keamanan data. Penggunaan internet dalam hal olah dan transmisi data rentan akan gangguan kejahatan siber. Terdapat banyak oknum yang memanfaatkan kemampuannya dalam menerobos jaringan komputer (hacker) untuk kepentingan bisnis bahkan hanya untuk sekedar aktualisasi diri (narsisme). Ketiga, gangguan komunikasi. Meskipun banyak tersedia aplikasi untuk memfasilitasi dialog tatap muka via internet, seringkali terjadi gangguan koneksi yang dapat menyebabkan tidak sampainya beberapa informasi dan berimbas pada ketidaksepahaman (miskomunikasi) antara komunikan dan komunikator.

Untuk mengatasi tantangan dan hambatan diatas, perguruan tinggi perlu melakukan pengendalian internal yang terstruktur dan sistematis. Upaya ini dilakukan untuk mengurangi bias pekerjaan yang berdampak terhadap terhambatnya pencapaian tujuan. Pengendalian internal terdiri dari beberapa komponen berikut: (1) Penetapan kebijakan dalam seluruh aspek organisasi. (2) Perumusan prosedur teknis kegiatan untuk menjamin kepatuhan, kepatutan dan kesesuaian luaran pekerjaan (Nainggolan, 2012). Pemenuhan komponen tersebut hendaknya didukung oleh unsur utama pengendalian internal, yaitu lingkungan pengendalian, sistem akuntansi, dan prosedur pengendalian. Untuk memastikan berjalannya proses pengendalian yang efektif, dapat dilakukan langkah-langkah dibawah ini:

1. Pengelompokkan berdasarkan orang dan jenis pekerjaan. Klasifikasi ini dilakukan untuk mengukur fisibilitas pekerjaan yang dimungkinkan untuk dilakukan di rumah.

2. Identifikasi faktor produksi. Mengetahui kemampuan sumber daya manusia (karyawan, dosen, mahasiswa) dalam memenuhi kebutuhan dasar untuk bekerja di rumah. Misal, kepemilikan laptop/desktop/HP berbasis android/IOS, kemampuan akses internet beserta stabilitasnya, dan kompetensi dalam menggunakan teknologi informasi.

3. Menentukan prosedur koordinasi. Prosedur organisasi tetap dilakukan dengan mengacu pada struktur organisasi dan tata kerja yang berlaku, memuat tentang wewenang, uraian 
pekerjaan, dan rentang kendali. Perbedaannya adalah proses komunikasi yang dilakukan secara online serta mengubah dokumen fisik menjadi soft file dan didistribusikan melalui email, fitur chatting daring, atau aplikasi khusus yang tersedia di kampus (misal: edisposisi).

4. Melakukan pemantauan. Bentuk supervisi yang dapat dilakukan dengan cara memantau output pekerjaan melalui sistem informasi. Misalnya melalui sistem informasi akademik (SIAKAD) dapat diketahui sebaran mata kuliah yang disampaikan oleh prodi, pengisian KRS yang dilakukan mahasiswa, pemenuhan kewajiban penyerahan nilai oleh dosen. Monitoring kehadiran karyawan dapat menggunakan media video conference melalui briefing berkala. Sedang presensi dosen dan mahasiswa dapat diukur dan dipantau dengan penggunaan aplikasi e-learning (classromm, google class, edLink), menempatkan staf jurusan/program studi sebagai admin dalam forum kuliah online tersebut. Selain itu, pelaporan melalui aplikasi PD. Dikti yang disediakan kementerian pendidikan dan kebudayaan bidang pendidikan tinggi dapat dijadikan alat ukur produktivitas dosen dalam melaksanakan penelitian dan pengabdian kepada masyarakat.

Implementasi tata kelola sistem informasi pada perguruan tinggi yang tepat guna dan tepat sasaran berpengaruh signifikan terhadap produktifitas manajemen. Konsistensi dalam melaksanakan langkah-langkah pengedalian internal dapat mendorong efektivitas bekerja dari rumah. Dibutuhkan komitmen dan kesadaran manajemen maupun individu pada perguruan tinggi untuk tetap dapat memelihara kualitas proses penyelenggaraan pendidikan, penelitian, dan pengabdian kepada masyarakat. Lebih dari itu, menjaga kelangsungan roda manajemen serta menjamin pencapaian tujuan organisasi secara efektif dan efisien.

\section{KESIMPULAN DAN IMPLIKASI}

Bekerja dari rumah menjadi sebuah konsesi bersama, budaya kolektif, keniscayaan pola kerja dalam menghadapi kondisi pandemi global covid-19. Perguruan tinggi harus mampu beradaptasi terhadap segala dinamika yang mengiringinya dengan tetap berperan menjalankan layanan pendidikan secara layak yang merupakan hak dasar warga negara. Untuk mendorong akselerasi manajemen dalam melaksanakan kegiatan bekerja dari rumah, perguruan tinggi hendaknya menerapkan tata kelola sistem informasi yang terukur dan terarah, sehingga aktivitas lembaga dapat berjalan dengan baik. Infrastruktur teknologi informasi, kebijakan, kompetensi sumber daya manusia, serta perilaku -kesadaran- individu 
Danial Kusumah, Sinta Maria Dewi

Vol. 5 No 2

ISSN : 2541-6995

E ISSN : 2580-5517

merupakan komponen yang berpengaruh terhadap efektivitas tata kelola sistem informasi di perguruan tinggi. Dengan adanya harmonisasi antar komponen dan sistem pengendalian internal yang baik, serta didukung oleh komitmen manajemen, aktivitas bekerja dari rumah dapat terlaksana secara efektif dan efisien.

\section{DAFTAR PUSTAKA}

Indrajit, R. E. (2011). Peranan Teknologi Informasi Pada Perguruan Tinggi: Menjawab $\begin{array}{llll}\text { Tantangan Pendidikan Abad ke-21. APTIKOM. https://ilmu- } & \end{array}$ pendidikan.net/sekolah/peran-tik-pengelolaan-institusi-pendidikan-tinggi

Jayani D. H. (2020). Sepuluh Media Sosial yang Paling Sering Digunakan di Indonesia. https://databoks.katadata.co.id/datapublish/2020/02/26/10-media-sosial-yang-palingsering-digunakan-di-indonesia. Diakses pada 18 Mei 2020.

Kantor Komunikasi dan Informatika. (2013). Penerapan Teknologi Informasi dan Komunikasi Untuk Mendukung Pengembangan E-Goverment Pemerintah Kota Bogor 2014-2018. Kota Bogor.

Nainggolan P. (2012). Manajemen Keuangan Lembaga Nirlaba. Jakarta: Yayasan IntegrasiEdukasi

Nugroho, L E. (2009). Pemanfaatan Teknologi Informasi di Perguruan Tinggi. Yogyakarta: Prajnya Media.

Peraturan Pemerintah Republik Indonesia Nomor 4 Tahun 2014 Tentang Penyelenggaraan Pendidikan Tinggi dan Pengelolaan Perguruan Tinggi. Lembaran Negara Republik Indonesia Tahun 2014. Jakarta.

Nomor 21 Tahun 2020 Tentang Pembatasan Sosial Berskala Besar Dalam Rangka Percepatan Penanganan Corona Virus Disease 2019 (Covid-19). Lembaran Negara Republik Indonesia Tahun 2020. Jakarta.

Peraturan Menteri Pendidikan dan Kebudayaan Indonesia Nomor 139 Tahun 2014 Tentang Pedoman Statuta dan Organisasi Peguruan Tinggi. Lembaran Negara Republik Indonesia Nomor 1670 Tahun 2014. Jakarta.

Peraturan Menteri Riset, Teknologi, Dan Pendidikan Tinggi Republik Indonesia Nomor 44 Tahun 2015 Tentang Standar Nasional Pendidikan Tinggi. Lembaran Negara Republik Indonesia Tahun 2015. Jakarta.

Nomor 62 Tahun 2016 Tentang Sistem Penjaminan Mutu Pendidikan Tinggi. Lembaran Negara Republik Indonesia Tahun 2015. Jakarta.

Sugiyono. (2016). Metode Penelitian Kuantitaif, Kualitatif dan HRD. Cet. 23. Bandung: Alfabeta 
Danial Kusumah, Sinta Maria Dewi

Vol. 5 No 2

ISSN : 2541-6995

E ISSN : 2580-5517

Tim Penyusun Kamus Pusat Bahasa. (2008) Kamus Bahasa Indonesia. Jakarta: Pusat Bahasa Departemen Pendidikan Nasional.

Tracey C. dan Moore J. (2004). Work-Life Balance and Working From Home. Social Policy and Society Journal. United Kingdom: Cambridge University Press

Undang-Undang Republik Indonesia Nomor 12 Tahun 2012 Tentang Pendidikan Tinggi. Lembaran Negara Republik Indonesia Tahun 2012. Jakarta.

World Health Organization (WHO).(2020). Situation Report-119 Coronavirus Disease (COVID-19).https://www.who.int/emergencies/diseases/novel-coronavirus2019/situation-reports/. Diakses pada 11 Mei 2020. 